\title{
Soil phosphorus budget in global grasslands and implications for management
}

Quanlai Zhou ${ }^{1,2}$, Stefani Daryanto², Zhiming Xin³, Zhimin Liu ${ }^{1}$, Minghu Liu ${ }^{3}$ Xue Cui $^{4}$, Lixin Wang ${ }^{2 *}$

${ }^{1}$ Institute of Applied Ecology, Chinese Academy of Sciences (CAS), Shenyang, Liaoning, 110016, China

${ }^{2}$ Department of Earth Sciences, Indiana University-Purdue University Indianapolis (IUPUI), Indianapolis, Indiana 46202, USA

${ }^{3}$ Experimental Center of Desert Forestry, Chinese Academy of Forestry, Dengkou 015200, Inner Mongolia, China.

${ }^{4}$ Prevention and Quarantine Bureau of Forestry Pest of Liaoning, Shenyang 110036, Liaoning Provence, China.

${ }^{*}$ Corresponding author:

Lixin Wang

Department of Earth Sciences

Indiana University-Purdue University Indianapolis

723 W. Michigan Street SL118 Indianapolis, IN 46202

Phone: (317) 2747464

Fax: (317) 2747966

Email: wang.iupui@gmail.com 


\section{Abstract}

Grasslands, accounting for one third of the world terrestrial land surface, are important in determining phosphorus (P) cycle at a global scale. Understanding the impacts of management on $\mathrm{P}$ inputs and outputs in grassland ecosystem is crucial in environmental management since a large amount of $\mathrm{P}$ is transported through rivers and groundwater and detained by sea reservoir every year. To better understand the P cycle in global grasslands, we mapped the distribution of different grassland types around the world and calculated the corresponding $\mathrm{P}$ inputs and outputs for each grassland type using data from the literature. The distribution map of $\mathrm{P}$ input and output revealed a nonequilibrium condition in many grassland ecosystems, with: (i) a greater extent of inputs than outputs in most managed grasslands, but (ii) a more similar inputs and outputs in the majority of natural grasslands. Based on the mass balance between $\mathrm{P}$ input and output, we developed a framework to achieve sustainable P management in grasslands and discussed the measures targeting a more balanced P budget. Greater challenge is usually found in heavily-managed than natural grasslands to establish the optimum amount of $\mathrm{P}$ for grass and livestock production while minimizing the adverse impacts on surface waters. This study provided a comprehensive assessment of $\mathrm{P}$ budget in global grasslands and such information will be critical in determining the appropriate $\mathrm{P}$ management measures for various grassland types across the globe.

Keywords: dryland, environmental risk monitoring, erosion, grazing, leaching, runoff 


\section{Introduction}

Grasslands are defined as "terrestrial ecosystems dominated by herbaceous and shrub vegetation and maintained by fire, grazing, drought and/or freezing temperatures. This definition includes vegetation covers with an abundance of non-woody plants and thus lumps together some savannas, woodlands, shrublands, and tundra, as well as more conventional grasslands” (White et al., 2000), making grasslands one of the most widespread biomes worldwide. Grasslands cover approximately $26 \%$ of the terrestrial area (Obermeier et al. 2016) and occur nearly on all continents except Antarctica (Rojas-Briales, 2015). Grasslands are most commonly found in arid and semi-arid zones (47\% of the world's grasslands), followed by humid (23\%), and cold (20\%) regions (White et al., 2000). Grasslands encompass, for examples, the savannas of Africa and Australia, the cerrado and campo of South America, the prairies of North America, and the steppes of Central Asia (Kemp and Michalk 2007). They cover about 117 million $\mathrm{km}^{2}$ of vegetated lands, and provide forage for more than 1800 million livestock units and wildlife populations (Kemp and Michalk, 2007; Rojas-Briales, 2015). These vast areas of lands support over 800 million of human populations with abundant natural resources for the production of food, fuel, fiber and medicine (Kemp and Michalk, 2007; Rojas-Briales, 2015). By integrating the International Vegetation Classification (IVC) with the map of terrestrial eco-regions of the world, Dixon et al. (2014) classified the following nine grassland types: (1) Alpine scrub, forb meadow and grassland; (2) boreal grassland, meadow and shrubland; (3) tropical montane shrubland, grassland and savanna; (4) tropical freshwater marsh, wet meadow and 
shrubland; (5) tropical lowland shrubland, grassland and savanna; (6) Mediterranean scrub, grassland and forb meadow; (7) temperate grassland, meadow and shrubland; (8) cool semi-desert scrub and grassland; and (9) warm semi-desert scrub and grassland (Fig. 1). These grassland types vary with regards to different ecosystem properties, ranging from $-0.3{ }^{\circ} \mathrm{C}$ to $27.4^{\circ} \mathrm{C}, 299 \mathrm{~mm}$ to $1555 \mathrm{~mm}, 0.165$ to 1.195 , and 36 to $340 \mathrm{~g}$ $\mathrm{m}^{-2}$ for temperature, precipitation, aridity index (defined as precipitation/potential evapotranspiration), and aboveground productivity, respectively (Parton et al., 1995).

Soil factors (e.g., parent material, nutrient content, and organic matter), which determine P content in grassland soils, are important contributors to the distribution of grassland types across the globe (Anderson and Talbot, 1965). The P content of soil parent materials, in particular, is closely related to total soil $\mathrm{P}$ because $\mathrm{P}$ is an element supplied by the parent material in natural ecosystems (Mage and Porder, 2013). With global phosphate rock depletion by biotic demands (e.g., agriculture), P gradually becomes one of the limiting elements of plant nutrients and vegetation productivity in terrestrial ecosystems, including in the grasslands (Koppelaar and Weikard, 2013; O’Halloran et al., 2010; Schlesinger et al., 1990). In northeastern Brazil, cultivated semi-arid areas in the region experienced a decline in soil $\mathrm{P}$ due to mineralization of organic $\mathrm{P}$ and subsequent transformation of inorganic $\mathrm{P}$ surplus to unavailable forms rather than a net export of $\mathrm{P}$ to the crops (Tiessen et al. 1992). Accordingly, soil $\mathrm{P}$ then becomes an important limiting element which governs the accumulation of soil organic matter, which could differ within a particular climate zone (Tate and Salcedo, 1988). In colder artic fell field soils, for example, a smaller P mineralization occurred in contrast 
to in warmer sub-Alpine heath soils where P mineralization occurred in a larger quantity (Jonasson et al. 1993).

According to its availability for plant acquisition, $\mathrm{P}$ in the soil can be classified into three different pools: soluble P, labile P, and non-labile P (Larsen, 1967; Sharpley, 1995). The labile $\mathrm{P}$ pool, being a combination of mineral and organic $\mathrm{P}$, is the main source of available P for plants (Sharpley, 1995), as the pool dissolves readily into soil solution by desorption from soil particles or by mineralization of organic P (Shen et al., 2011). The other two pools, on the other hand, are rarely used by plants. Only a small amount of soluble P is taken up by plant directly in orthophosphate or organic forms (McDowell and Sharpley, 2001). The non-labile P, despite their abundance (i.e., 9599\% of total P), is so inert and resistant to mineralization (Sharpley et al., 1995), and consequently it is released very slowly into the soil solution (Marschner and Rengel, 2007). All of these three pools, however, remain in a dynamic conversion by physicochemical reactions such as sorption and desorption (labile and soluble P), precipitation and dissolution (non-labile and labile P), mineralization and immobilization (inorganic and organic P) (Daly et al., 2015; Haygarth et al., 2005; Shen et al., 2011). They also share variable proportions in different soil types as various edaphic variables, such as soil temperature, moisture, $\mathrm{pH}$, and plant depletion (Sharpley et al., 1995) determine their states. These dynamic conversions along with variability in soil properties contribute to the difficulties in accurately determining fertilizer $\mathrm{P}$ application rate, despite the presence of soil test P (STP), since the concentration of soil 
$\mathrm{P}$ varies with soil, plant species, and climatic factors, as well as analytical methodologies.

Considering the complexity of measuring $\mathrm{P}$ rate and its transfer (Haygarth et al. 2005), a reasonably simple approach (e.g., a nutrient mass balance) to facilitate the comparison of P loads across different grassland types is necessary as currently such information is critically lacking. A nutrient mass balance can be defined as an accounting approach for nutrient inputs and the outputs (Gourley et al., 2007). This is a useful technique to quantify and to predict nutrient deficit and surplus, although there are considerable assumptions associated with scaling up the measurements from different scales (e.g., plot, field, farm-gate, and farm-system scale measurements) by linear aggregation modeling, spatial statistics census, and remote-sensing approaches (Borbor-Cordova et al., 2006; Cobo et al., 2010; Gourley et al., 2007). In this review, P balance is calculated as the difference between inputs and outputs within pre-defined spatial domain, in this case different grassland types and the balance is expressed in the amount of P per unit area (Cobo et al., 2010).

Under the assumption that a positive balance indicated P surplus, representing potential loss to the ecosystem while negative balance indicated soil nutrient depletion (Cobo et al., 2010; Bouwman et al., 2013), we considered that ideally: (i) P inputs should be equal with the outputs to prevent soil P accumulation and depletion (Hooda et al., 2001; Ma et al., 2009) and (ii) P loss to environment should be lower than the threshold for environmental safety (McDowell and Sharpley, 2004) in either natural or managed grasslands. Currently most of grassland ecosystems are in their imbalance 
state because of various $\mathrm{P}$ inputs and output pathways coupling with various biogeochemical, hydrological and anthropic factors are occuring at different temporal and spatial scales (Haygarth et al., 2005; Wang et al., 2015). Using P mass balance for determining sustainable productivity in all grassland ecosystems (Haygarth et al., 1998a), we aimed to develop a clear framework for different grassland types and a sound $\mathrm{P}$ management for determining $\mathrm{P}$ application rate, mitigating $\mathrm{P}$ transfer to water, and restoring degraded grassland environments.

Although during the past two decades, significant progress has been made to understand the contents of soil P pools, some processes in the cycling of $\mathrm{P}$ in grasslands, including their pathways and amount of P loss, remain unclear. For example, P balance in some types of grassland (e.g., tropical freshwater marsh and wet meadow, Alpine scrub and forb meadow and cool semi-desert grassland) and the dynamics of P inputs and outputs as a result of changes in management practices and climate variability are rarely reported. In this review, we collected literature studies and used mass balance approach (Bedada et al., 2016; Haas et al., 2007; Haygarth et al., 1998a) to quantify the balance of $\mathrm{P}$ inputs and outputs in both natural and managed grasslands and to identify the appropriate management options. Since the main purposes of this review are: (i) to illustrate the potential P input and output pathways and their controlling mechanisms in global grasslands, (ii) to obtain a thorough understanding of the P balance in different types of grasslands across the globe, and (iii) to discuss strategies for better grassland management practices on the basis of corresponding $\mathrm{P}$ balance, we did not include different chemical reactions that occurred between different $\mathrm{P}$ forms in soil and water 
that have been discussed elsewhere (e.g., McLaughlin et al., 2011; Haygarth et al., 1998b; and Simard et al., 2000).

\section{Methods}

Phosphorus mass balance, a quantitative tool used to represent $\mathrm{P}$ inputs and outputs, is defined as the difference between $\mathrm{P}$ inputs and outputs from a particular grassland ecosystem (Obour et al., 2011; Oelmann et al., 2007). The inputs and outputs of $\mathrm{P}$ involved in P cycling of grassland ecosystems are shown in Fig. 2. Generally, P mass balance in grassland ecosystems is calculated by the following equation (Bedada et al., 2016; Domburg et al., 2000; Haygarth et al., 1998a):

P balance $=$ inputs - outputs $=(\mathrm{M}+\mathrm{A}+\mathrm{F}+\mathrm{O})-(\mathrm{W}+\mathrm{L}+\mathrm{R}+\mathrm{H})$, where $\mathrm{M}=$ Mineral weathering, $\mathrm{A}=$ Atmospheric deposition and dust, $\mathrm{F}=$ Fertilizer and manure, $\mathrm{O}=$ Other inputs (e.g., bought cattle, manure, cattle feed, and bedding, etc.), $\mathrm{W}=$ Wind erosion, $\mathrm{L}=$ Leaching loss, $\mathrm{R}=$ Runoff loss, $\mathrm{H}=$ Herd production.

To build the this review, peer-reviewed journal articles published in English from 1900 to 2016 were collected based on Web of Science search using the following sets of topic keywords: (i) phosphorus budget or phosphorus balance or phosphorus cycling or phosphorus weathering or phosphorus deposition or phosphorus fertilizer or phosphorus leaching or phosphorus runoff or phosphorus wind erosion, and (ii) grassland or meadow or shrubland or savanna or prairie or steppe or pasture. Of the 443 articles found, only articles that met the following criteria were included in the database: (i) phosphorus inputs and outputs was found under grassland ecosystems (181 articles removed), and (ii) any of the $\mathrm{P}$ inputs (weathering, fertilizer, precipitation, dust, and 
products imported from other ecosystems) or outputs (surface runoff, wind erosion, leaching, and products exported from the ecosystems) were considered in either managed or natural grasslands (129 articles removed). The final results were 123 articles, including 39 articles used to build the database of this paper (Supplementary Table S1-S2). We defined natural grasslands (include semi-natural grasslands) as grasslands that support wild animals and are less affected by cattle grazing and agricultural practices, while managed grasslands refer to those that are intensively affected by cattle grazing, farming or cattle raising (Bilotta et al., 2007).

The data were then recorded separately for inputs, outputs, and balances in natural grassland and managed grasslands (Supplementary Tables S1-S2). The highest and lowest values for outputs, inputs, and balances found in each grassland type were selected to depict the whole arrays of the spectrum and the summary is presented in Table 1. We, however, did not include any chemical reactions or physical changes of $\mathrm{P}$ that are cycled in the system when calculating the P balance (Oelmann et al., 2007; Haygarth et al., 1998).

\section{Results and Discussion}

According to the definition of $\mathrm{P}$ balance above, we calculated $\mathrm{P}$ budget (i.e., inputs and outputs) based on literature values reported in global grasslands. Details of P input, output and balance for each type of grasslands are provided in Table 1.

\subsection{Natural grasslands}

In general, we found that $\mathrm{P}$ balance in natural grasslands was mostly neutral (i.e., $\mathrm{P}$ inputs $\approx$ outputs), ranging from -2.01 to $1.2 \mathrm{~kg} \mathrm{P} \mathrm{ha}^{-1}$ (Table 1; Supplementary Table 
S1; Fig. 3). Phosphorus input and output were also low, ranging from $0.001 \mathrm{~kg} \mathrm{P} \mathrm{ha}^{-1}$ to $13.9 \mathrm{~kg} \mathrm{P} \mathrm{ha}^{-1}$ and from $0.001 \mathrm{~kg} \mathrm{P} \mathrm{ha}^{-1}$ to $12.7 \mathrm{~kg} \mathrm{P} \mathrm{ha}^{-1}$ for input and output, respectively (Table 1; Supplementary Table S1; Fig. 3). In the southeastern Alpine meadow of Switzerland, for example, $\mathrm{P}$ input $\left(0.30 \sim 0.99 \mathrm{~kg} \mathrm{P} \mathrm{ha}^{-1}\right)$ by feces from wild red deer was almost equal to the output $\left(0.21 \sim 0.92 \mathrm{~kg} \mathrm{P} \mathrm{ha}^{-1}\right)$ by animal grazing, leading to an almost equilibrium balance of $0.08 \sim 0.10 \mathrm{~kg} \mathrm{P} \mathrm{ha}^{-1}$ (Schütz et al., 2006). Since $\mathrm{P}$ fluxes were very low, it might take up to 1,660 years or more to deplete the P-rich soils with annual P loss of $0.083 \mathrm{~kg} \mathrm{ha}^{-1}$ caused by grazing of red deer on Alp Stabelcho (Schütz et al., 2006). Some exceptions, however, occurred where P output was double the amount of input such as in Sare Yorobana, southern Senegal, Africa (Manlay et al., 2004; Supplementary Table S1), resulting from the cattle grazing in the savanna grassland. When outputs exceed inputs in a grassland ecosystem, soil total P and available $\mathrm{P}$ will decrease gradually, and $\mathrm{P}$ will then become a limiting factor for productivity (Li et al., 2005; Zhao et al., 2006).

The major components of $\mathrm{P}$ inputs in natural grasslands are atmospheric dust depositions (Haygarth et al., 1998a; Hoffmann et al., 2008), weathering of minerals (Woodmansee and Duncan, 1980; Newman, 1995), and precipitation (LópezHernández et al., 1994). Meanwhile, the major outputs are wild animal (Schütz et al., 2006), water drainage and surface runoff (López-Hernández et al., 1994; Schlesinger et al., 1999) and wind erosion (Li et al. 2007; Li et al. 2009).

\subsubsection{Inputs}

3.1.1.1 Atmosphere and dust depositions 
Dusts are fine particles that are eroded from land surface by wind and suspended in the atmosphere (Field et al., 2010). Although there are no appreciable gaseous atmospheric P compounds in the P cycle, dust deposition is a non-negligible source of $\mathrm{P}$ in grassland soils (Compton et al., 2000). Over the years, $\mathrm{P}$ additions from airborne dusts mediated by a sparse vegetation canopy can lead to the development of fertile islands (Newman, 1995; Stock et al., 1999) and become an important nutrient input for the long-term maintenance of grassland productivity (Okin et al., 2004).

Dust deposition varies with climate, land use, vegetation cover, topography, and animal grazing (Bhattachan et al., 2015; Harrison et al., 2001; Hoffmann et al., 2008; Li et al., 2007). The rates could differ from $1.3 \mathrm{~g} \mathrm{~m}^{-2} \mathrm{~d}^{-1}$ in open, grazed grasslands to $2.4 \mathrm{~g} \mathrm{~m}^{-2} \mathrm{~d}^{-1}$ in the vegetated, ungrazed sites, and could reach $29-33 \%$ higher in the leeward slopes than that in windward slopes, summits and plane positions (Hoffmann et al., 2008). In some temperate grasslands, strong dust deposition occurred during the spring seasons and the addition of $\mathrm{P}$ by dust input could range from $7 \mathrm{~kg} \mathrm{P} \mathrm{ha}^{-2} \mathrm{year}^{-1}$ (0.02 $\left.\mathrm{kg} \mathrm{ha}^{-1} \mathrm{day}^{-1}\right)$ during spring in the Horqin Sandy Land of eastern Inner Mongolia, northern China (Li et al. 2004) to $9 \mathrm{~kg} \mathrm{P} \mathrm{ha}^{-2}$ year $^{-1}\left(0.025 \mathrm{~kg} \mathrm{P} \mathrm{ha}^{-2}\right.$ day $^{-1}$ ) in semiarid steppes of Xilinhaote Inner Mongolia, China (Yan et al., 2011).

\subsubsection{Weathering of minerals}

The major input of $\mathrm{P}$ in soil is the chemical weathering of primary $\mathrm{P}$ mineral apatite whose rates range from 0.01 to $1 \mathrm{~kg} \mathrm{P} \mathrm{ha}^{-1}$ year $^{-1}$ in terrestrial ecosystems (Newman, 1995). In grassland ecosystems, rock weathering involves insolation cracks, freezethaw action, wind abrasion, and breakdown by microorganisms (e.g., carbonic acid 
formed by fungi, cyanobacteria, and lichens) (Belnap, 2011). These rates of chemical weathering are mostly determined by climate (e.g., temperature and precipitation) (White and Blum, 1995), although other factors such as the types of rock, surface area of mineral particles, effective area of the particles contacted with water, and dissolved chemicals released from plant roots and microorganisms (Newman, 1995) also play some roles in determining weathering rate. In highly weathered soils, various secondary P minerals from primary $\mathrm{P}$ mineral apatite have been the dominant components of soil material (Walker and Syers, 1976).

\subsubsection{Precipitation}

Phosphorus input from precipitation is generally low (less than $0.2 \mathrm{~kg} \mathrm{P}^{-1} \mathrm{year}^{-}$ 1, López-Hernández et al., 1994), and varies with P concentration in the rainfall and the amount of precipitation. For example, in Módulo Experimental de Mantecal, a natural savanna located between the rivers Arauca and Apure, Venezuela, P input was only 0.193 kg P ha ${ }^{-1}$ year $^{-1}$ from 2038 mm year ${ }^{-1}$ precipitation (López-Hernández et al., 1994).

\subsubsection{Outputs}

\subsubsection{Wild Animal}

Grazing by wild animals, including ungulates, rodents and grasshoppers, is an important output pathway in natural grasslands. It has been reported that $\mathrm{P}$ removal rates by red deer ranged from 0.08 to $0.95 \mathrm{~kg} \mathrm{P} \mathrm{ha}^{-1} \mathrm{y}^{-1}$, increased with increasing vegetation coverage and soil-P pool, in a subalpine grassland ecosystem in the southeastern part of Switzerland (Schütz et al., 2006). 


\subsubsection{Drainage and leaching}

In contrast to heavy P loss in the drainage of managed grasslands, P loss from soil available $\mathrm{P}$ in the drainage and leachate of natural grasslands is generally small. In the Chihuahuan Desert grassland of New Mexico, for example, the loss was only 0.0378 kg $\mathrm{P} \mathrm{ha}^{-1}$ during a 30-min heavy rainfall simulation $\left(146 \mathrm{~mm} \mathrm{~h}^{-1}\right)$ (Schlesinger et al., 1999). In other natural grasslands (i.e., Horqin Sand Land Inner Mongolia, northeastern China), $\mathrm{P}$ loss was higher and could reach $2.6 \mathrm{~kg} \mathrm{P} \mathrm{ha}^{-1}, 1.6 \mathrm{~kg} \mathrm{P} \mathrm{ha}^{-1}$ and $1.2 \mathrm{~kg} \mathrm{P} \mathrm{ha-}$

${ }^{1}$, respectively, from soils taken from active, semi-stabilized, and stabilized sand dune in degraded grassland with $20 \mathrm{~mm}$ simulated rainfall that occurred every 2 days over 14 days (equivalent to $140 \mathrm{~mm}$ of total precipitation) (Zhou et al. 2013).

\subsubsection{Surface runoff}

Since the amount of P loading in surface runoff is greatly affected by fertilization rate and to a lesser extent, the types, topography, precipitation (intensity and duration), land use, and field management practices (Sharpley, 1995; Watson and Matthews, 2008; Yu et al., 2006), runoff losses of P were usually very small in natural, unfertilized grasslands (Schlesinger et al. 1999). The annual runoff losses of $\mathrm{P}$, monitored from unfertilized plots in the Sevilleta National Wildlife Refuge in central New Mexico, USA, for example, only ranged from 0.05 to $0.25 \mathrm{~kg} \mathrm{ha}^{-1}$ (Turnbull et al., 2011).

\subsubsection{Wind erosion}

Since the rate of nutrient loss due to wind erosion is strongly affected by vegetation cover, wind erosion has become a major pathway of nutrient loss in shrub-encroached or degraded sandy grasslands ( $\mathrm{Li}$ et al. 2007, Li et al. 2008). Phosphorus output 
resulting from wind erosion varies with the level of degradation in the corresponding grassland. For example, $\mathrm{P}$ output in four types of sand dune ecosystems originated from a grass-dominated steppe were $0.08 \mathrm{~kg} \mathrm{ha}^{-1}$ (slightly degraded fixed sand dune community), $0.34 \mathrm{~kg} \mathrm{ha}^{-1}$ (moderately degraded semifixed sand dune community), 0.74 $\mathrm{kg} \mathrm{ha}^{-1}$ (severely degraded semi-shifting sand dune community) and $1.75 \mathrm{~kg} \mathrm{ha}^{-1}$ (most severely degraded shifting sand dune community) (Li et al., 2009).

\subsection{Managed grasslands}

In managed grasslands, we found variable $\mathrm{P}$ balances (i.e., positive balance (inputs>outputs) or negative balance (inputs< $<$ outputs)), ranging from -42.0 to $126 \mathrm{~kg} \mathrm{P}$ $\mathrm{ha}^{-1}$, with inputs ranging from 0 to $355 \mathrm{~kg} \mathrm{P} \mathrm{ha}^{-1}$ and outputs from 0 to $68.7 \mathrm{~kg} \mathrm{P} \mathrm{ha}^{-1}$

(Table 1; Supplementary Table S2; Fig. 4). The majority of managed grasslands, however, had greater P input than output. The amount of input could range from 1.5 to 7.6 times greater than output. For example at River Ythan catchment in NE Scotland, P input (41 kg P ha ${ }^{-1}$ ) from seven farm types of seeds, fertilizer, feed, animals, and atmosphere, was 2.3 times of total outputs (18 $\left.\mathrm{kg} \mathrm{P} \mathrm{ha}^{-1}\right)$ from crops, eggs, milk, and animals (Domburg et al., 2000). With positive balance (i.e., inputs>outputs), P surplus that accumulated in the soils increased P loss potential to runoff and subsurface flow (Chen et al., 2006; McDowell and Sharpley, 2004), especially in sandy soil with low sorption capacity (Wu and Tiessen, 2002). Large input of $\mathrm{P}$ fertilizer or manure application saturated the soil $\mathrm{P}$ sorption capacity, inducing a large rate of loss, especially when the farm is managed using flood irrigation or fertilized before heavy rain (Sinaj et al., 2002; Toor et al., 2005). Positive P balance due to continuous $\mathrm{P}$ 
fertilization would induce the risk of nutrient losses to the surface and groundwater (e.g., eutrophication in river, lake and ocean) (Haygarth et al., 1998; McDowell and Sharpley, 2004; Murphy et al., 2015).

Although rare, negative $\mathrm{P}$ balance also occurred in managed grasslands due to, for examples high stocking rate and animal production while placing restriction on fertilizer application rate and farm-gate imports (Murphy et al., 2015). While these efforts were initially conducted to increase P use efficiency and decrease P surplus, over time, negative $\mathrm{P}$ balance could decrease the sustainability of grassland ecosystem productivity. Negative P balance increased the potential for soil P deficiency resulting from greater P outputs (e.g., heavy grazing, herd products, wind erosion, leaching) than inputs (e.g., low or without fertilizer and manure application). We should therefore aim for a neutral $\mathrm{P}$ balance to maintain sustainable soil $\mathrm{P}$ reserve and environmental water safety, which could be achieved for example by converting from conventional or intensive farming to organic farming that had an almost neutral P balance (Haas et al., 2007).

The inputs of $\mathrm{P}$ in managed grasslands, in addition to the aforementioned components in natural grasslands, are fertilizer and manure application (Haygarth et al., 1998; Domburg et al., 2000; Pote et al., 2009), purchased feed, seeds, and herds (Haas et al., 2007). Meanwhile, the outputs include wind erosion (Li et al., 2005), herd production (Steinshamn et al., 2004; Haygarth et al., 1998), and other outputs similar to those in natural grasslands.

\subsubsection{Inputs}




\subsubsection{Fertilizer and manure application}

The application of inorganic P fertilizer and manure is an important agricultural practices for managed grasslands since weathering of minerals is rarely sufficient to sustain soil organic matter content and grass productivity (Haygarth et al., 1998a; Heathwaite et al., 1998; Kilcher et al., 1965; Koppelaar and Weikard, 2013; Pote et al., 2009). The application rates vary with soil and fertilizer types, which range: (i) from 1 kg P ha ${ }^{-1}$ in relatively unweathered soils of arid environments to more than $200 \mathrm{~kg} \mathrm{P}$ $\mathrm{ha}^{-1}$ in oxide rich tropical or volcanic soils (Tiessen, 2008) and (ii) from $72.7 \mathrm{~kg} \mathrm{ha}^{-1}$ for inorganic fertilizer to about $69-118 \mathrm{~kg} \mathrm{P}^{\mathrm{P}} \mathrm{ha}^{-1}$ for organic fertilizer (manure) (Heathwaite et al., 1998; Pote et al., 2009). This surplus of P input from chemical fertilizer or manure tend to accumulate in the soil (Hooda et al., 2001) and after a longterm fertilizer application, it will increase soil $\mathrm{P}$ availability, although some of this $\mathrm{P}$ will gradually be transformed into less reactive forms (Heathwaite et al., 1998; Kilcher et al., 1965; Pote et al., 2009; Tiessen et al., 1982).

\subsubsection{Other inputs in grassland}

Other inputs of P such as P in purchased feed, imported manure, purchased seeds, and feed in the form of concentrates, beddings, or purchased herds (Haygarth et al., 1998a; Steinshamn et al., 2004) may vary greatly (i.e., 4-60\% of total inputs), depending on land use and management practices. In an intensive dairy farm, additional $\mathrm{P}$ inputs in the form of concentrates $\left(27.1 \mathrm{~kg} \mathrm{ha}^{-1}\right)$ and chopped straw for bedding $(0.1$ $\mathrm{kg} \mathrm{ha}^{-1}$ ) could account for $62 \%$ of total P inputs (Haygarth et al., 1998a). Conversely, a

hill sheep farm that covered a large land area was less dependent on these inputs 
(Haygarth et al., 1998). The purchased seeds $\left(0.3 \mathrm{~kg} \mathrm{ha}^{-1}\right)$, feed (1.6 kg ha-1), imported manure $\left(0.6 \mathrm{~kg} \mathrm{ha}^{-1}\right)$, and bought cattle $\left(0.2 \mathrm{~kg} \mathrm{ha}^{-1}\right)$ only took up about $4.4 \%$ of total annual inputs (Steinshamn et al., 2004; Woodmansee and Duncan, 1980). Intensification of livestock production during the last few decades has generally increased the use of these supplementary inputs in exchange for open-range feeding system (Bouwman et al. 2013), particularly in heavily managed grassland, such as dairy farms (Steinshamn et al., 2004).

\subsubsection{Outputs}

\subsubsection{Wind erosion}

Vegetation cover, particularly grass (Li et al. 2008), is the most important factor that influences the intensity of wind erosion, apart from the amount of litter on the ground, soil surface hardness and soil moisture (Li et al., 2005). Inappropriate management practices that reduce vegetation cover such as overgrazing and land reclamation, make grasslands highly erodible (Li et al., 2002). For example, in Horqin sandy grassland of eastern Mongolia, China, wind speed could reach between 3 and 4 $\mathrm{m} \mathrm{s}^{-1}$ with gales as strong as $17 \mathrm{~m} \mathrm{~s}^{-1}$ during spring seasons, which generated $5.46 \mathrm{~kg}$ ha ${ }^{-1} \mathrm{P}$ loss (Li et al., 2004). In in the rangeland Korla Xinjiang northwest China, P loss resulted from wind erosion was $3.64 \mathrm{~kg} \mathrm{P} \mathrm{ha}^{-1} \mathrm{year}^{-1}$, calculated according to the erosion modulus and the range of soil P concentration (Dong et al. 2000).

\subsubsection{Livestock output}

Livestock export is an important output of $\mathrm{P}$ in managed grassland ecosystem. The amount, however, differs between that in livestock-intensive and in minimally- 
managed agricultural grasslands (Chaneton et al., 1996; Domburg et al., 2000). Location-induced management types also contribute to the amount of $\mathrm{P}$ output generated by the primary production of grassland, livestock managements, and P input (Haygarth et al., 1998a; Steinshamn et al., 2004). Most of intensively-managed grassland ecosystems, such as dairy farms, are located in flat grassland with high fertilizer input and stocking rate, resulting in high output of P (Haygarth et al., 1998a). Conversely, minimally-management ecosystems, such as sheep farms, are generally situated in unimproved natural grasslands or hills and uplands with low or no fertilizer, low stocking rate, and consequently low output of P (Haygarth et al., 1998a). Annual estimates indicated that $\mathrm{P}$ output was only $0.9 \mathrm{~kg} \mathrm{ha}^{-1}$ via cattle export in a grazed, natural Argentinian grassland (Chaneton et al., 1996) or $0.14 \mathrm{~kg} \mathrm{ha}^{-1}$ in a typical extensive hill sheep farm ecosystem (Haygarth et al., 1998a), as opposed to 16.1 kg ha

${ }^{1}$ of P output in a typical intensive dairy farm with high fertilizer input (Haygarth et al., 1998a).

\subsubsection{Leaching}

Although traditionally it was assumed that P leaching was negligible in most soils since $\mathrm{P}$ was strongly fixed and immobilized by the soil matrix and microorganisms (Hedley et al., 1982; McDowell and Sharpley, 2001; Shen et al., 2011; Turner and Haygarth, 1999), over the last few decades, many studies reported that total $\mathrm{P}$ concentration increased significantly in runoff and drainage water through leaching from soils amended with manure and inorganic fertilizer of P (Heckrath et al., 1995; McDowell and Sharpley, 2001; McDowell and Sharpley, 2004). Total P in drainage 
water consists of two dominant forms: the total particulate P (TPP) and total dissolved P (TDP). TPP, associated with soil colloids and organic matter, is bound to soil particles transported through cracks and fissures (Djodjic et al., 2000). TDP, on the other hand, contains dissolved reactive phosphorus (DRP) and dissolved organic phosphorus (DOP); both are transported through soil solution (Heckrath et al., 1995; McDowell and Sharpley, 2004; Haygarth et al., 2005). DRP commonly forms the largest fraction in drainage water (i.e., 66-86\%; Heckrath et al., 1995), most likely due to its high solubility.

Two consecutive steps, loading followed by transport step, are involved in the process of leaching of P from different $\mathrm{P}$ sources (Jensen et al., 1998). During the first step, P is released from P sources (e.g., soil P pools, mineral fertilizers, and manures) into soil solution by dissolution and desorption (Haygarth et al., 2005). During the second step, $\mathrm{P}$ is moved vertically and horizontally with water to drainage and ground water (Kang et al., 2011). There are several factors that may influence P leaching losses such as soil properties (e.g., soil texture and land use), environmental conditions (e.g., intensity and temporal distribution of the rainfall or irrigation, and soil structure), and management practices (e.g., type of fertilizer and rate of application, time of application relative to rainfall, and type of vegetation) (Jensen et al., 1998; Leinweber et al., 1999; Weaver et al., 1988). Coarse-textured soils lost more $\mathrm{P}$ than fine-textured soils (Leinweber et al., 1999) and the total annual P loss found drainage water ranged from $0.68 \mathrm{~kg} \mathrm{ha}^{-1}$ to $1.05 \mathrm{~kg} \mathrm{ha}^{-1}, 0.52 \mathrm{~kg} \mathrm{ha}^{-1}$ to $0.65 \mathrm{~kg} \mathrm{ha}^{-1}$, and $0.03 \mathrm{~kg} \mathrm{ha}^{-1}$ to $0.24 \mathrm{~kg} \mathrm{ha}^{-}$ ${ }^{1}$ from sandy, loamy, and clayed soils, respectively (Djodjic et al., 2000; Leinweber et 
al., 1999). Types of irrigation also strongly affects the amount of $\mathrm{P}$ loss with higher level of irrigation (e.g., flood irrigation) creating more loss (0.85-2.3 $\left.\mathrm{kg} \mathrm{ha}^{-1} \mathrm{year}^{-1}\right)$ than lower level of irrigation ( 0.054 to $0.265 \mathrm{~kg} \mathrm{ha}^{-1} \mathrm{year}^{-1}$ ) under the same soil texture (Sinaj et al., 2002). Land management such as heavy application of manures is also responsible for a large quantity of P leaching because dissolved organic carbon (DOC) in manures may decrease P adsorption, enhancing P mobility (Kang et al., 2011). It is estimated that P loss from loamy soils with preferential flow could reach up to $5 \mathrm{~kg} \mathrm{ha}^{-}$ ${ }^{1}$ over the whole growing season in a grassland fertilized with cattle slurry P (Hooda et al., 1999). In contrast, the number was only $1.29 \mathrm{~kg} \mathrm{ha}^{-1}$ in similar, unfertilized grasslands (Stamm et al., 1998). Approximately 17 to 81\% of the applied P (animal manures) lost from the surface soil $(10-30 \mathrm{~cm})$ and an increase of orthophosphate $\mathrm{P}$ concentration was found in the subsoil (50-100 cm) in sandy grassland because P could easily be transported downward in this type of soil (Gillman, 1973; Koopmans et al., 2007; Ozanne et al., 1961).

\subsubsection{Surface runoff}

Surface runoff is another main output pathway of $\mathrm{P}$ caused by the erosion of TPP, desorption of labile $\mathrm{P}$, and dissolution of non-labile $\mathrm{P}$ from surface soil (Heathwaite et al., 1998; Murphy et al., 2015). Excessive mineral and manure application on managed grassland soils often leads to P-enriched surface soils (and subsequent elevated soil test P, STP), which are very susceptible to runoff losses (Mittelstet et al., 2011; Turtola and Jaakkola, 1995).

Since the amount of P loading in surface runoff is greatly affected by fertilization 
rate, such amount could reach between 1.2 and $1.6 \mathrm{~kg} \mathrm{ha}^{-1}$ from cultivated, fertilized heavy clay soils in Finland (Turtola and Jaakkola, 1995). However, in-stream uptake by riverbank or silt will effectively reduce dissolved inorganic P in runoff, decreasing P impact on water body (Ensign et al., 2006).

\subsection{Phosphorus management practices in grasslands}

Phosphorus balance is an important factor determining the sustainability of soil $\mathrm{P}$ in grassland ecosystems. Management of $\mathrm{P}$ in grasslands should consider Best Management Practices (BMP), which include controlling $\mathrm{P}$ input source and their mobilization, decreasing loss, and balancing the inputs and the outputs to minimize $\mathrm{P}$ impact on water bodies (Haygarth et al., 2005; Sharpley et al., 2006). According to the difference between input and output, $\mathrm{P}$ balance can be classified into the following three categories in grassland ecosystems (Fig. 5):

\subsubsection{Neutral (equilibrium) P balance}

Net balance is approximately zero (Fig. 3). In natural grassland ecosystems, $\mathrm{P}$ output caused by leaching, runoff and animal grazing is low and can be balanced by atmospheric deposition and weathering (Chaneton et al., 1996; Woodmansee and Duncan, 1980). For example, in the Sevilleta National Wildlife Refuge in central New Mexico, USA, there was a net balance of $0.14 \mathrm{~kg} \mathrm{P} \mathrm{ha}^{-1}$, resulting from $0.32 \mathrm{~kg} \mathrm{ha}^{-1}$ of P input and $0.18 \mathrm{~kg} \mathrm{ha}^{-1}$ of $\mathrm{P}$ output (Turnbull et al., 2011). Since this balance occurs mostly in the natural reserves, the main objective of grassland management is to minimize human disturbance (Chaneton et al., 1996; Haygarth et al., 1998).

\subsubsection{Positive balance}


Here $\mathrm{P}$ accumulation occurs in the soil as it receives more $\mathrm{P}$ (from P fertilizer and manure application) than plant requirement and other losses, resulting in an increase of potential P loss through leaching and surface runoff. Conducting frequent soil testing (STP and DRP testing) and water monitoring is therefore the recommended management strategy under this situation. The limits for DRP and TP level should be below $0.01 \mathrm{mg} \mathrm{P}^{-1}$ and $0.1 \mathrm{mg} \mathrm{P}^{-1}$, respectively, under which the flowing waters can then be discharged to other water bodies (Dodds et al., 1998; McDowell and Sharpley, 2004).

Since over-fertilization of $\mathrm{P}$ becomes an important source of nonpoint pollution to surface water and subsurface drainage during irrigation and heavy storms, apart from reducing or temporarily stopping $\mathrm{P}$ fertilizer and manure application, approaches should be taken to mitigate the amount of $\mathrm{P}$ loss. These approaches, which in general, must consider the spatial and temporal patterns of $\mathrm{P}$ release, have been reviewed in much details by, for examples, Watson and Kay (2001) and Bilotta et al. (2007). These reviews suggest to consider manure management (manure storage, transporting, incorporation or injection to the soil), feeding strategy (reducing $\mathrm{P}$ in diet), and runoff management (adjusting fertilizer application with climate, enhancing vegetation coverage) (Bergstrom et al., 2015; Sharpley et al., 2006) to reduce P loss. Using the above management, it would usually take about 3 to 6 years for soil DRP to reach the environmentally acceptable level (below $0.01 \mathrm{mg} \mathrm{L}^{-1}$ ) (McDowell and Sharpley, 2004) or for the STP to decrease below the threshold value (100 $\mathrm{mg} \mathrm{kg}^{-1}$ Mehlich-3 extractable P). According to Watson and Foy (2001), an experiment in 'De Marke’ dairy farm using 
a combination of the above strategies (e.g., reducing inputs in fertilizer and concentrates by more than half) could substantially lower the annual P surpluses without having an adverse effect on milk production. Shifting the majority of inorganic P fertilizer to onfarm-generated organic P fertilizer could reduce P surplus (Murphy et al., 2015), although method of slurry application and climate remained important in determining P losses (McConnell et al., 2016). In places where water erosion occurs regularly, it is important to conduct runoff management by increasing or protecting vegetation coverage in combination with the above risk control management practices. At the same time, DRP concentration in flowing water should be monitored for evaluating the effectiveness of the management (Fig. 5).

After the environmental impairment caused by $\mathrm{P}$ accumulation is reduced, the BMPs should be implemented. These may include, the incorporation of conceptual models to predict P loss from freshly-applied fertilizer based on factors such as storm frequency, the timing and method of $\mathrm{P}$ application, the type of fertilizer applied and $\mathrm{P}$ transport mode to the aquatic ecosystem (Withers et al. 2003). Soil managements (e.g., occasional soil tillage) can decrease P leaching loss by disturbing soil macropores and disrupt the transporting pathway (Geohring et al., 2001). Soil survey (i.e., sampling and testing) should be taken at a minimum of every 3 years to identify the critical STP concentration (Dodd and Mallarino, 2005; Sharpley et al., 2006). The application strategies involve controlling $\mathrm{P}$ application rate (e.g., slightly above P uptake by plants roots) and timing (e.g., avoid fertilizer applications before heavy rainfall) in order to 
decrease massive loss of P by leaching and runoff (Dodd and Mallarino, 2005; Sharpley et al., 2006).

\subsubsection{Negative balance}

Here P loss occurs from the soil as a result of over-consumption of P by plant uptake or loss by leaching, runoff, and wind erosion. Negative P balance generally occurs in barren soils with low $\mathrm{P}$ in natural or unmanaged grasslands. Under this situation, depletion of P by root uptake in soil solution speeds up the replenishment of P released from available pools (e.g., adsorption of inorganic $\mathrm{P}$ and mobilization of organic P) in the short term (Shen et al., 2011). For such grasslands, large removal of soil P occurs mostly from reduced vegetation cover and land degradation caused by human interference (e.g., over grazing) and climate change. However, climatic and biological factors often constrain passive recovery particularly in the dry areas, and guidelines or techniques for active restoration are costly, including the use of land enclosure, restoration of vegetated landscape, or terrace (Sharpley et al., 2006). Moreover, conservation of the remaining grasslands to sustain biodiversity and productivity is seldom enforced due to economic considerations. Therefore, a less costly approach (e.g., government incentive) for applying annual P fertilizers, even as low as $25 \mathrm{~kg} \mathrm{P}_{2} \mathrm{O}_{5} \mathrm{ha}^{-1}$, could alleviate the deficiency in soil $\mathrm{P}$ and resulted in improved pasture production, even during dry years (Osman et al., 1991).

Negative P balance, however, could still occur in heavily-managed grasslands, which at times have abundant $\mathrm{P}$ input. In this situation, $\mathrm{P}$ deficit could happen due to intensive production, and/or leaching and runoff losses to surface water. The former, 
however, is usually deliberate, to reduce high $\mathrm{P}$ loss (e.g., mining of soil P reserves built up over previous years or decades) (Murphy et al., 2015). Thus, the primary objective of $\mathrm{P}$ management is to increase $\mathrm{P}$ use efficiency by optimizing the amount of $\mathrm{P}$ inputs (fertilizer and manure application) and minimizing P loss (e.g., enhancing vegetation cover, using conservation tillage, and installing wetlands) to lower the amount of total P load from runoff and erosion (Bergstrom et al., 2015). Structure liming, using calcium oxide $(\mathrm{CaO})$ or hydrated lime $\left(\mathrm{Ca}(\mathrm{OH})_{2}\right)$ mixed with a clay soil to improve soil structure, stability, porosity, and aggregate strength, was also an effective method to reduce particulate-bound P leaching on soils with high P status (Bergstrom et al., 2015). These BMPs should be conducted in the grassland ecosystem to maintain sustainable productivity until the environmental impairment is reduced to an acceptable level.

Using the flow chart (Fig. 5), we can argue that natural grasslands usually require a lower level of P management since they have low P balance (Woodmansee and Duncan, 1980). Greater challenge, however, occurs in heavily-managed grasslands since we have to maximize P-use efficiency by meeting the $\mathrm{P}$ requirements for grass and livestock production while minimizing the adverse effects on surface waters to achieve sustainable P management (Sharpley et al., 2000). In this case, producers and government should work simultaneously to decide which strategy is well-suited to the environmental condition by considering the specific soils, climate, topography, and management factors, for example, by avoiding $\mathrm{P}$ application during rainy season (Bergstrom et al., 2015; Sharpley et al., 2006) or maximizing livestock dispersion and movement to minimize the spatial transfer of P (i.e., from grazed to watering or resting 
areas; Stott and Turner, 1998). Converting to organic farming system that recycled most of its waste and eliminating the use of mineral-P fertilizer could also address the concern about environmental safety that arose from conventional or intensive farming system (Haas et al., 2007).

\section{Summary}

Using $\mathrm{P}$ balance approach, our synthesis revealed the quantitative extents of $\mathrm{P}$ input and output in different grassland types, with the largest range of P balance was found in heavily managed temperate grasslands (i.e., between -42 and $126 \mathrm{~kg} \mathrm{P} \mathrm{ha}^{-1}$ ) and to a lesser extent, in Mediterranean grasslands (i.e., between -5.4 and 20.4 kg P ha-1) and in warm semi-dessert grassland (i.e., between -1.0 and $25.8 \mathrm{~kg} \mathrm{P} \mathrm{ha}^{-1}$ ). Although less variation of P balance was reported in natural grasslands (i.e., between -2.01 and $1.2 \mathrm{~kg}$ $\mathrm{P} \mathrm{ha}^{-1}$ ), none of them showed an absolute equilibrium state of $\mathrm{P}$ inputs and outputs. We acknowledge, however, that there are some limitations in using $\mathrm{P}$ balance approach due to the data availability from literature. Different input or output pathways remained unrecorded in some grassland ecosystems, particularly those located in the developing countries. Fewer data involving P management were available for example, in arid or boreal regions, because low population density and/or primary productivity constrained the economic development, research and management practices. Nevertheless, we provided a comprehensive assessment of $\mathrm{P}$ budget in global grasslands and suggested practical measures to achieve sustainable soil P management. Such information will be critical in determining the appropriate P management measures for different grassland types across the globe. 


\section{Acknowledgement}

This research is supported by the National Natural Science Foundation of China (Grant no. 3080016), the overseas studying program of Chinese Academy Sciences, and LW acknowledges partial support from the U.S. Department of Agriculture (201451130-22492) and Schlumberger Foundation Faculty for the Future fellowship for SD.

\section{References}

Anderson, G., Talbot, L., 1965. Soil factors affecting the distribution of the grassland types and their utilization by wild animals on the Serengeti plains, Tanganyika. J. Ecol., 33-56.

Bedada, W., Lemenih, M., Karltun, E., 2016. Soil nutrient build-up, input interaction effects and plot level $\mathrm{N}$ and $\mathrm{P}$ balances under long-term addition of compost and NP fertilizer. Agric. Ecosyst. Environ. 218, 220-231.

Belnap, J., 2011. Biological phosphorus cycling in dryland regions, Phosphorus in Action. Springer, pp. 371-406.

Bergstrom, L., Kirchmann, H., Djodjic, F., Kyllmar, K., Ulen, B., Liu, J., Andersson, H., Aronsson, H., Borjesson, G., Kynkaanniemi, P., Svanback, A., Villa, A., 2015. Turnover and Losses of Phosphorus in Swedish Agricultural Soils: LongTerm Changes, Leaching Trends, and Mitigation Measures. J. Environ. Qual. 44, 512-523. 
Bhattachan, A., D'Odorico, P., Okin, G.S., 2015. Biogeochemistry of dust sources in Southern Africa. J. Arid. Environ. 117, 18-27.

Bilotta, G.S., Brazier, R.E., Haygarth, P.M., 2007. The impacts of grazing animals on the quality of soils, vegetation, and surface waters in intensively managed grasslands, in: Sparks, D.L. (Ed.), Advances in Agronomy, Vol 94, pp. 237-280.

Borbor-Cordova, M.J., Boyer, E.W., McDowell, W.H., Hall, C.A., 2006. Nitrogen and phosphorus budgets for a tropical watershed impacted by agricultural land use: Guayas, Ecuador. Biogeochemistry 79, 135-161.

Bouwman, L., Goldewijk, K.K., Van Der Hoek, K.W., Beusen, A.H., Van Vuuren, D.P., Willems, J., Rufino, M.C., Stehfest, E., 2013. Exploring global changes in nitrogen and phosphorus cycles in agriculture induced by livestock production over the 1900-2050 period. Proc. Natl Acad. Sci. 110, 20882-20887.

Chaneton, E., Lemcoff, J., Lavado, R., 1996. Nitrogen and phosphorus cycling in grazed and ungrazed plots in a temperate subhumid grassland in Argentina. J. Appl. Ecol., 291-302.

Chapin, F.S., Barsdate, R.J., Barel, D., 1978. Phosphorus cycling in alaskan coastal tundra - hypothesis for the regulation of nutrient cycling. Oikos 31, 189-199.

Chen, G.C., He, Z.L., Stoffella, P.J., Yang, X.E., Yu, S., Calvert, D., 2006. Use of dolomite phosphate rock (DPR) fertilizers to reduce phosphorus leaching from sandy soil. Environ. Pollut. 139, 176-182. 
Cobo, J.G., Dercon, G., Cadisch, G., 2010. Nutrient balances in African land use systems across different spatial scales: A review of approaches, challenges and progress. Agric. Ecosyst. Environ 136, 1-15.

Compton, J., Mallinson, D., Glenn, C., Filippelli, G., Follmi, K., Shields, G., Zanin, Y., 2000. Variations in the global phosphorus cycle, in: Glenn, C.R., Prevot-Lucas, L., Lucas, J. (Eds.), Marine Authigenesis: From Global to Microbial. SEPM Society of Sedimentary Geology.

Daly, K., Styles, D., Lalor, S., Wall, D.P., 2015. Phosphorus sorption, supply potential and availability in soils with contrasting parent material and soil chemical properties. Eur. J. Soil Sci. 66, 792-801.

Dixon, A., Faber - Langendoen, D., Josse, C., Morrison, J., Loucks, C., 2014. Distribution mapping of world grassland types. J. Biogeogr. 41, 2003-2019.

Djodjic, F., Ulén, B., Bergström, L., 2000. Temporal and spatial variations of phosphorus losses and drainage in a structured clay soil. Water Res. 34, 16871695.

Dodd, J.R., Mallarino, A.P., 2005. Soil-test phosphorus and crop grain yield responses to long-term phosphorus fertilization for corn-soybean rotations. Soil Sci. Soc. Am. J. 69, 1118-1128.

Dodds, W.K., Jones, J.R., Welch, E.B., 1998. Suggested classification of stream trophic state: Distributions of temperate stream types by chlorophyll, total nitrogen, and phosphorus. Water Res. 32, 1455-1462. 
Domburg, P., Edwards, A.C., Sinclair, A.H., Chalmers, N.A., 2000. Assessing nitrogen and phosphorus efficiency at farm and catchment scale using nutrient budgets. J. Sci. Food Agric. 80, 1946-1952.

Dong, Z., Wang, X., Liu, L., 2000. Wind erosion in arid and semiarid China: an overview. J. Soil Water Conserv. 55, 439-444.

Ensign, S.H., McMillan, S.K., Thompson, S.P., Piehler, M.E., 2006. Nitrogen and phosphorus attenuation within the stream network of a coastal, agricultural watershed. J. Environ. Qual. 35, 1237-1247.

Field, J.P., Belnap, J., Breshears, D.D., Neff, J.C., Okin, G.S., Whicker, J.J., Painter, T.H., Ravi, S., Reheis, M.C., Reynolds, R.L., 2010. The ecology of dust. Front. Ecol. Environ. 8, 423-430.

Foy, R.H., Bailey, J.S., Lennox, S.D., 2002. Mineral balances for the use of phosphorus and other nutrients by agriculture in Northern Ireland from 1925 to 2000 methodology, trends and impacts of losses to water. Ir. J. Agr. Food Res. 41, 247263.

Friesen, D.K., Rao, I.M., Thomas, R.J., Oberson, A., Sanz, J., 1997. Phosphorus acquisition and cycling in crop and pasture systems in low fertility tropical soils. Plant Soil 196, 289-294.

Geohring, L.D., McHugh, O.V., Walter, M.T., Steenhuis, T.S., Akhtar, M.S., Walter, M.F., 2001. Phosphorus transport into subsurface drains by macropores after manure applications: Implications for best manure management practices. Soil Sci 166, 896-909. 
Gillman, G., 1973. Studies on some deep sandy soils in Cape York Peninsula, North Queensland. 3. Losses of applied phosphorus and sulphur. Anim. Prod. Sci. 13, 418-422.

Gourley, C.J.P., Dougherty, W.J., Weaver, D.M., Aarons, S.R., Awty, I.M., Gibson, D.M., Hannah, M.C., Smith, A.P., Peverill, K.I., 2012. Farm-scale nitrogen, phosphorus, potassium and sulfur balances and use efficiencies on Australian dairy farms. Anim. Prod. Sci. 52, 929-944.

Gourley, C.J.P., Powell, J.M., Dougherty, W.J., Weaver, D.M., 2007. Nutrient budgeting as an approach to improving nutrient management on Australian dairy farms. Aust. J. Exp. Agric. 47, 1064-1074.

Haas, G., Deittert, C., Koepke, U., 2007. Farm-gate nutrient balance assessment of organic dairy farms at different intensity levels in Germany. Renew. Agric. Food Syst. 22, 223-232.

Harrison, S.P., Kohfeld, K.E., Roelandt, C., Claquin, T., 2001. The role of dust in climate changes today, at the last glacial maximum and in the future. Earth-Sci. Rev. 54, 43-80.

Haygarth, P., Chapman, P., Jarvis, S., Smith, R., 1998a. Phosphorus budgets for two contrasting grassland farming systems in the UK. Soil Use Manage. 14, 160-167.

Haygarth, P.M., Condron, L.M., Heathwaite, A.L., Turner, B.L., Harris, G.P., 2005. The phosphorus transfer continuum: Linking source to impact with an interdisciplinary and multi-scaled approach. Sci. Total Environ. 344, 5-14. 
Haygarth, P., Hepworth, L., Jarvis, S., 1998b. Forms of phosphorus transfer in hydrological pathways from soil under grazed grassland. Eur. J. Soil Sci. 49, 6572.

Heathwaite, A., Griffiths, P., Parkinson, R., 1998. Nitrogen and phosphorus in runoff from grassland with buffer strips following application of fertilizers and manures. Soil Use Manage. 14, 142-148.

Heckrath, G., Brookes, P., Poulton, P., Goulding, K., 1995. Phosphorus leaching from soils containing different phosphorus concentrations in the Broadbalk experiment. J. Environ. Qual. 24, 904-910.

Hedley, M., Stewart, J., Chauhan, B., 1982. Changes in inorganic and organic soil phosphorus fractions induced by cultivation practices and by laboratory incubations. Soil Sci. Soc. Am. J. 46, 970-976.

Hesketh, N., Brookes, P., 2000. Development of an indicator for risk of phosphorus leaching. J. Environ. Qual 29, 105-110.

Heathwaite, A., Griffiths, P., Parkinson, R., 1998. Nitrogen and phosphorus in runoff from grassland with buffer strips following application of fertilizers and manures. Soil Use Manage. 14, 142-148.

Hoffmann, C., Funk, R., Wieland, R., Li, Y., Sommer, M., 2008. Effects of grazing and topography on dust flux and deposition in the Xilingele grassland, Inner Mongolia. J. Arid. Environ. 72, 792-807. 
Hooda, P., Moynagh, M., Svoboda, I., Edwards, A., Anderson, H., Sym, G., 1999. Phosphorus loss in drainflow from intensively managed grassland soils. J. Environ. Qual. 28, 1235-1242.

Hooda, P., Rendell, A., Edwards, A., Withers, P., Aitken, M., Truesdale, V. 2000. Relating soil phosphorus indices to potential phosphorus release to water. J. Environ. Qual. 29: 1166-1171.

Hooda, P., Truesdale, V., Edwards, A., Withers, P., Aitken, M., Miller, A., Rendell, A., 2001. Manuring and fertilization effects on phosphorus accumulation in soils and potential environmental implications. Adv. Environ. Res. 5, 13-21.

Jensen, M.B., Jørgensen, P.R., Hansen, H.C.B., Nielsen, N.E., 1998. Biopore mediated subsurface transport of dissolved orthophosphate. J. Environ. Qual. 27, 11301137.

Jonasson, S., Havstrom, M., Jensen, M., Callaghan, T.V., 1993. In-situ mineralization of nitrogen and phosphorus of arctic soils after perturbations simulating climatechange. Oecologia 95, 179-186.

Käding, H., 2006. Effect of varied fertilization and cutting frequency on forage yields, phosphorus and potassium contents and nutrient balance of fen grassland. Arc. Agro. Soil Sci. 52, 261-267.

Kang, J., Amoozegar, A., Hesterberg, D., Osmond, D.L., 2011. Phosphorus leaching in a sandy soil as affected by organic and inorganic fertilizer sources. Geoderma $161,194-201$. 
Kemp, D., Michalk, D., 2007. Towards sustainable grassland and livestock management. J. Agric. Sci. 145, 543-564.

Kilcher, M., Smoliak, S., Hubbard, W., Johnston, A., Gross, A., McCurdy, E., 1965. Effects of inorganic nitrogen and phosphorus fertilizers on selected sites of native grassland in western Canada. Can. J. Plant Sci. 45, 229-237.

Koopmans, G., Chardon, W., McDowell, R., 2007. Phosphorus movement and speciation in a sandy soil profile after long-term animal manure applications. J. Environ. Qual. 36, 305-315.

Koppelaar, R., Weikard, H.P., 2013. Assessing phosphate rock depletion and phosphorus recycling options. Global Environ. Change 23, 1454-1466.

Larsen, S., 1967. Soil phosphorus. Adv. Agron. 19, 151-210.

Leinweber, P., Meissner, R., Eckhardt, K.U., Seeger, J., 1999. Management effects on forms of phosphorus in soil and leaching losses. Eur. J. Soil Sci. 50, 413-424.

Li, F.R., Kang, L.F., Zhang, H., Zhao, L.Y., Shirato, Y., Taniyama, I., 2005. Changes in intensity of wind erosion at different stages of degradation development in grasslands of Inner Mongolia, China. J. Arid. Environ. 62, 567-585.

Li, F.R., Zhao, L.Y., Zhang, H., Zhang, T.H., Shirato, Y., 2004. Wind erosion and airborne dust deposition in farmland during spring in the Horqin Sandy Land of eastern Inner Mongolia, China. Soil Till. Res. 75, 121-130.

Li, F.R., Zhao, W.Z., Liu, J.L., Huang, Z.G., 2009. Degraded vegetation and wind erosion influence soil carbon, nitrogen and phosphorus accumulation in sandy grasslands. Plant Soil 317, 79-92. 
Li, J., Okin, G.S., Alvarez, L., Epstein, H., 2007. Quantitative effects of vegetation cover on wind erosion and soil nutrient loss in a desert grassland of southern New Mexico, USA. Biogeochemistry 85, 317-332.

Li, S.G., Harazono, Y., Zhao, H.L., He, Z.Y., Chang, X.L., Zhao, X.Y., Zhang, T.H., Oikawa, T., 2002. Micrometeorological changes following establishment of artificially established artemisia vegetation on desertified sandy land in the Horqin sandy land, China and their implication on regional environmental change. J. Arid. Environ. 52, 101-119.

López-Hernández, D., García, M., Niño, M., 1994. Input and output of nutrients in a diked flooded savanna. J. Appl. Ecol., 303-312.

Ma, Y., Li, J., Li, X., Tang, X., Liang, Y., Huang, S., Wang, B., Liu, H., Yang, X., 2009. Phosphorus accumulation and depletion in soils in wheat-maize cropping systems: Modeling and validation. Field Crop Res. 110, 207-212.

Manlay, R.J., Ickowicz, A., Masse, D., Feller, C., Richard, D., 2004. Spatial carbon, nitrogen and phosphorus budget in a village of the West African savanna-II. Element flows and functioning of a mixed-farming system. Agric. Syst. 79, 83107.

Marschner, P., Rengel, Z., 2007. Nutrient Cycling in Terrestrial Ecosystems. SpringerVerlag, Berlin Heidelberg.

Mage, S.M., Porder, S., 2013. Parent Material and Topography Determine Soil Phosphorus Status in the Luquillo Mountains of Puerto Rico. Ecosystems 16, 284-294. 
McConnell, D.A., Doody, D.G., Elliott, C.T., Matthews, D.I., Ferris, C.P., 2016. Impact of slurry application method on phosphorus loss in runoff from grassland soils during periods of high soil moisture content. Irish J. Agric. Food Res. DOI: 10.1515/ijafr-2016-0004.

McDowell, R., Sharpley, A., 2001. Approximating phosphorus release from soils to surface runoff and subsurface drainage. J. Environ. Qual. 30, 508-520.

McDowell, R.W., Sharpley, A.N., 2004. Variation of phosphorus leached from Pennsylvanian soils amended with manures, composts or inorganic fertilizer. Agric. Ecosyst. Environ. 102, 17-27.

Messiga, A.J., Ziadi, N., Jouany, C., Virkajarvi, P., Suomela, R., Sinaj, S., Belanger, G., Stroia, C., Morel, C., 2015. Soil test phosphorus and cumulative phosphorus budgets in fertilized grassland. Ambio 44, S252-S262.

Mittelstet, A.R., Heeren, D.M., Fox, G.A., Storm, D.E., White, M.J., Miller, R.B., 2011. Comparison of subsurface and surface runoff phosphorus transport rates in alluvial floodplains. Agric. Ecosyst. Environ 141, 417-425.

Murphy, P.N.C., Mellander, P.E., Melland, A.R., Buckley, C., Shore, M., Shortle, G., Wall, D.P., Treacy, M., Shine, O., Mechan, S., Jordan, P., 2015. Variable response to phosphorus mitigation measures across the nutrient transfer continuum in a dairy grassland catchment. Agric. Ecosyst. Environ. 207, 192202.

Newman, E., 1995. Phosphorus inputs to terrestrial ecosystems. J. Ecol., 713-726. 
O'Halloran, L.R., Shugart, H.H., Wang, L., Caylor, K.K., Ringrose, S., Kgope, B., 2010. Nutrient limitations on aboveground grass production in four savanna types along the Kalahari Transect. J. Arid. Environ. 74, 284-290.

Obermeier, W.A., LehnertL.W., KammannC.I., Müller C., Grünhage L., Luterbacher J., Erbs M., Moser G., Seibert R., and Yuan N., 2016. Reduced CO² fertilization effect in temperate $\mathrm{C}^{3}$ grasslands under more extreme weather conditions. Nat. Clim. Change. DOI: 10.1038/nclimate3191.

Obour, A., Silveira, M., Vendramini, J., Jawitz, J., O'Connor, G., Sollenberger, L., 2011. A phosphorus budget for bahiagrass pastures growing on a typical Florida Spodosol. Agron. J. 103, 611-616.

Oelmann, Y., Kreutziger, Y., Temperton, V.M., Buchmann, N., Roscher, C., Schumacher, J., Schulze, E.-D., Weisser, W.W., Wilcke, W., 2007. Nitrogen and phosphorus budgets in experimental grasslands of variable diversity. J. Environ. Qual. 36, 396-407.

Okin, G., Mahowald, N., Chadwick, O., Artaxo, P., 2004. Impact of desert dust on the biogeochemistry of phosphorus in terrestrial ecosystems. Global Biogeochem. Cycle. DOI: 10.1029/2003GB002145.

Okin, G.S., Gillette, D.A., 2001. Distribution of vegetation in wind dominated landscapes: Implications for wind erosion modeling and landscape processes. J. Geophys. Res. 106, 9673-9683. 
Osman, A.E., Cocks, P.S., Russi, L., Pagnotta, M.A., 1991. Response of Mediterranean grassland to phosphate and stocking rates - biomass production and botanical composition. J. Agric. Sci. 116, 37-46.

Ozanne, P., Kirkton, D., Shaw, T., 1961. The loss of phosphorus from sandy soils. Crop Pasture Sci. 12, 409-423.

Parton, W., Scurlock, J., Ojima, D., Schimel, D., Hall, D., 1995. Impact of climate change on grassland production and soil carbon worldwide. Global Change Biol. $1,13-22$.

Perez Corona, M., Klundert, I.v.d., Verhoeven, J., 1996. Availability of organic and inorganic phosphorus compounds as phosphorus sources for Carex species. New Phytol. 133, 225-231.

Pote, D.H., Way, T.R., Sistani, K.R., Moore Jr, P.A., 2009. Water-quality effects of a mechanized subsurface-banding technique for applying poultry litter to perennial grassland. J. Environ. Manage. 90, 3534-3539.

Rojas-Briales, E., 2015. Sparing grasslands: FAO's active role. Science 347, 12111211.

Rowarth, J.S., Tillman, R.W., Gillingham, A.G., Gregg, P.E.H., 1992. Phosphorus balances in grazed, hill-country pastures - the effect of slope and fertilizer input. N. Z. J. Agric. Res. 35, 337-342.

Schlesinger, W., Reynolds, J., Cunningham, G., Huenneke, L., Jarrell, W., Virginia, R., Whitford, W., 1990. Biological feedbacks in global desertification. Science 247, 1043-1048. 
Schlesinger, W.H., Abrahams, A.D., Parsons, A.J., Wainwright, J., 1999. Nutrient losses in runoff from grassland and shrubland habitats in Southern New Mexico: I. Rainfall simulation experiments. Biogeochemistry 45, 21-34.

Schütz, M., Risch, A.C., Achermann, G., Thiel-Egenter, C., Page-Dumroese, D.S., Jurgensen, M.F., Edwards, P.J., 2006. Phosphorus translocation by red deer on a subalpine grassland in the Central European Alps. Ecosystems 9, 624-633.

Sharpley, A., Daniel, T., Gibson, G., Bundy, L., Cabrera, M., Sims, T., Stevens, R., Lemunyon, J., Kleinman, P., Parry, R., 2006. Best Management Practices to Minimize Agricultural Phosphorus Impacts on Water Quality, Agricultural Research. United States Department of Agriculture.

Sharpley, A., Foy, B., Withers, P., 2000. Practical and innovative measures for the control of agricultural phosphorus losses to water: An overview. J. Environ. Qual. 29, 1-9.

Sharpley, A., Smith, S., 1985. Fractionation of inorganic and organic phosphorus in virgin and cultivated soils. Soil Sci. Soc. Am. J. 49, 127-130.

Sharpley, A.N., 1995. Soil phosphorus dynamics: agronomic and environmental impacts. Ecol. Eng. 5, 261-279.

Sharpley, A.N., Robinson, J.S., Smith, S.J., 1995. Bioavailable phosphorus dynamics in agricultural soils and effects on water quality. Geoderma 67, 1-15.

Shen, J., Yuan, L., Zhang, J., Li, H., Bai, Z., Chen, X., Zhang, W., Zhang, F., 2011. Phosphorus dynamics: from soil to plant. Plant Physiol. 156, 997-1005. 
Simard, R.R., Beauchemin, S., Haygarth, P.M., 2000. Potential for preferential pathways of phosphorus transport. J. Environ. Qual. 29, 97-105.

Sinaj, S., Stamm, C., Toor, G.S., Condron, L.M., Hendry, T., Di, H.J., Cameron, K.C., Frossard, E., 2002. Phosphorus exchangeability and leaching losses from two grassland soils. J. Environ. Qual. 31, 319-330.

Stamm, C., Flühler, H., Gächter, R., Leuenberger, J., Wunderli, H., 1998. Preferential transport of phosphorus in drained grassland soils. J. Environ. Qual. 27, 515-522.

Steinke, K., Kussow, W.R., Stier, J.C., 2013. Potential Contributions of Mature Prairie and Turfgrass to Phosphorus in Urban Runoff. J. Environ. Qual. 42, 1176-1184.

Steinshamn, H., Thuen, E., Bleken, M.A., Brenøe, U.T., Ekerholt, G., Yri, C., 2004. Utilization of nitrogen $(\mathrm{N})$ and phosphorus $(\mathrm{P})$ in an organic dairy farming system in Norway. Agr. Ecosyst. Environ. 104, 509-522.

Stock, W., Dlamini, T., Cowling, R., 1999. Plant induced fertile islands as possible indicators of desertification in a succulent desert ecosystem in northern Namaqualand, South Africa. Plant Ecol. 142, 161-167.

Stott, P., Turner, M.D., 1998. Long - term effects of daily grazing orbits on nutrient availability in Sahelian West Africa: 2. Effects of a phosphorus gradient on spatial patterns of annual grassland production. J. Biogeogr. 25, 683-694.

Tate, K.R., Salcedo, I., 1988. Phosphorus control of soil organic-mater accumulation and cycling. Biogeochemistry 5, 99-107.

Tiessen, H., 2008. Phosphorus in the global environment, The ecophysiology of plantphosphorus interactions. Springer, pp. 1-7. 
Tiessen, H., Salcedo, I.H., Sampaio, E., 1992. Nutrient and soil organic-mater dynamics under shifting cultivation in semiarid northeastern Brazil. Agric. Ecosyst. Environ. 38, 139-151.

Tiessen, H., Stewart, J., Bettany, J., 1982. Cultivation effects on the amounts and concentration of carbon, nitrogen, and phosphorus in grassland soils. Agron. J. 74, 831-835.

Toor, G., Condron, L., Cade - Menun, B., Di, H., Cameron, K., 2005. Preferential phosphorus leaching from an irrigated grassland soil. Eur. J. Soil Sci. 56, 155168.

Toor, G.S., Condron, L.M., Di, H.J., Cameron, K.C., Sims, J.T., 2004. Assessment of phosphorus leaching losses from a free draining grassland soil. Nutri. Cycl. Agroecosyst. 69, 167-184.

Turnbull, L., Wainwright, J., Brazier, R.E., 2011. Nitrogen and phosphorus dynamics during runoff events over a transition from grassland to shrubland in the southwestern United States. Hydrol. Processes 25, 1-17.

Turner, B.L., Haygarth, P.M., 1999. Phosphorus leaching under cut grassland. Water Sci. Technol. 39, 63-67.

Turtola, E., Jaakkola, A., 1995. Loss of phosphorus by surface runoff and leaching from a heavy clay soil under barley and grass ley in Finland. Acta Agric. Scand. 45, 159-165. 
Vadas, P.A., Busch, D.L., Powell, J.M., Brink, G.E., 2015. Monitoring runoff from cattle-grazed pastures for a phosphorus loss quantification tool. Agric. Ecosyst.Environ. 199, 124-131.

Walker, T., Adams, A.R., 1958. Studies on soil organic matter: I. Influence of phosphorus content of parent of materials on accumulations of carbon, nitrogen, sulfur, and organic phosphorus in grassland soils. Soil Sci. 85, 307-318.

Walker, T.W., Syers, J.K., 1976. The fate of phosphorus during pedogenesis. Geoderma 15, 1-19.

Wang, L., Manzoni, S., Ravi, S., Riveros-Iregui, D., Caylor, K. 2015. Dynamic interactions of ecohydrological and biogeochemical processes in water-limited systems. Ecosphere 6, 1-27.

Watson, C.J., Foy, R.H., 2001. Environmental impacts of nitrogen and phosphorus cycling in grassland systems. Outlook Agric. 30, 117-127.

Watson, C.J., Matthews, D.I., 2008. A 10-year study of phosphorus balances and the impact of grazed grassland on total P redistribution within the soil profile. Eur. J. Soil Sci. 59, 1171-1176.

Weaver, D., Ritchie, G., Anderson, G., Deeley, D., 1988. Phosphorus leaching in sandy soils. I. Short-term effects of fertilizer applications and environmental conditions. Soil Res. 26, 177-190.

Weaver, D.M., Wong, M.T.F., 2011. Scope to improve phosphorus (P) management and balance efficiency of crop and pasture soils with contrasting P status and buffering indices. Plant Soil 349, 37-54. 
White, A.F., Blum, A.E., 1995. Effects of climate on chemical_weathering in watersheds. Geochim. Cosmochim. Act. 59, 1729-1747.

White, R.P., Murray, S., Rohweder, M., Prince, S., Thompson, K., 2000. Grassland ecosystems. World Resources Institute. Washington DC, U.S.A.

Woodmansee, R., Duncan, D., 1980. Nitrogen and phosphorus dynamics and budgets in annual grasslands. Ecology, 893-904.

Wu, R.G., Tiessen, H., 2002. Effect of land use on soil degradation in alpine grassland soil, China. Soil Sci. Soc. Am. J. 66, 1648-1655.

Yan, Y., Xu, X., Xin, X., Yang, G., Wang, X., Yan, R., Chen, B., 2011. Effect of vegetation coverage on aeolian dust accumulation in a semiarid steppe of northern China. Catena 87, 351-356.

Yu, S., He, Z.L., Stoffella, P.J., Calvert, D.V., Yang, X.E., Banks, D.J., Baligar, V.C., 2006. Surface runoff phosphorus (P) loss in relation to phosphatase activity and soil P fractions in Florida sandy soils under citrus production. Soil Biol. Biochem. 38, 619-628.

Zhao, H., Yi, X., Zhou, R., Zhao, X., Zhang, T., Drake, S., 2006. Wind erosion and sand accumulation effects on soil properties in Horqin Sandy Farmland, Inner Mongolia. Catena 65, 71-79.

Zhang, Z., Wieland, R., Reiche, M., Funk, R., Hoffmann, C., Li, Y., Sommer, M., 2012. Identifying sensitive areas to wind erosion in the Xilingele grassland by computational fluid dynamics modelling. Ecol. Inf. 8, 37-47. 
Zhou, Q.L., Jiang, D.M., Liu, Z.M., Li, X.H., Alamusa, M., 2013. Effect of Leaching on Loss of Soil Phosphorus in Different Types of Sand Dune in Horqin Sandy Land, China. Adv. Mater. Res. 726, 3818-3827. 
Table 1. Phosphorus balance in different types of grassland ecosystems.

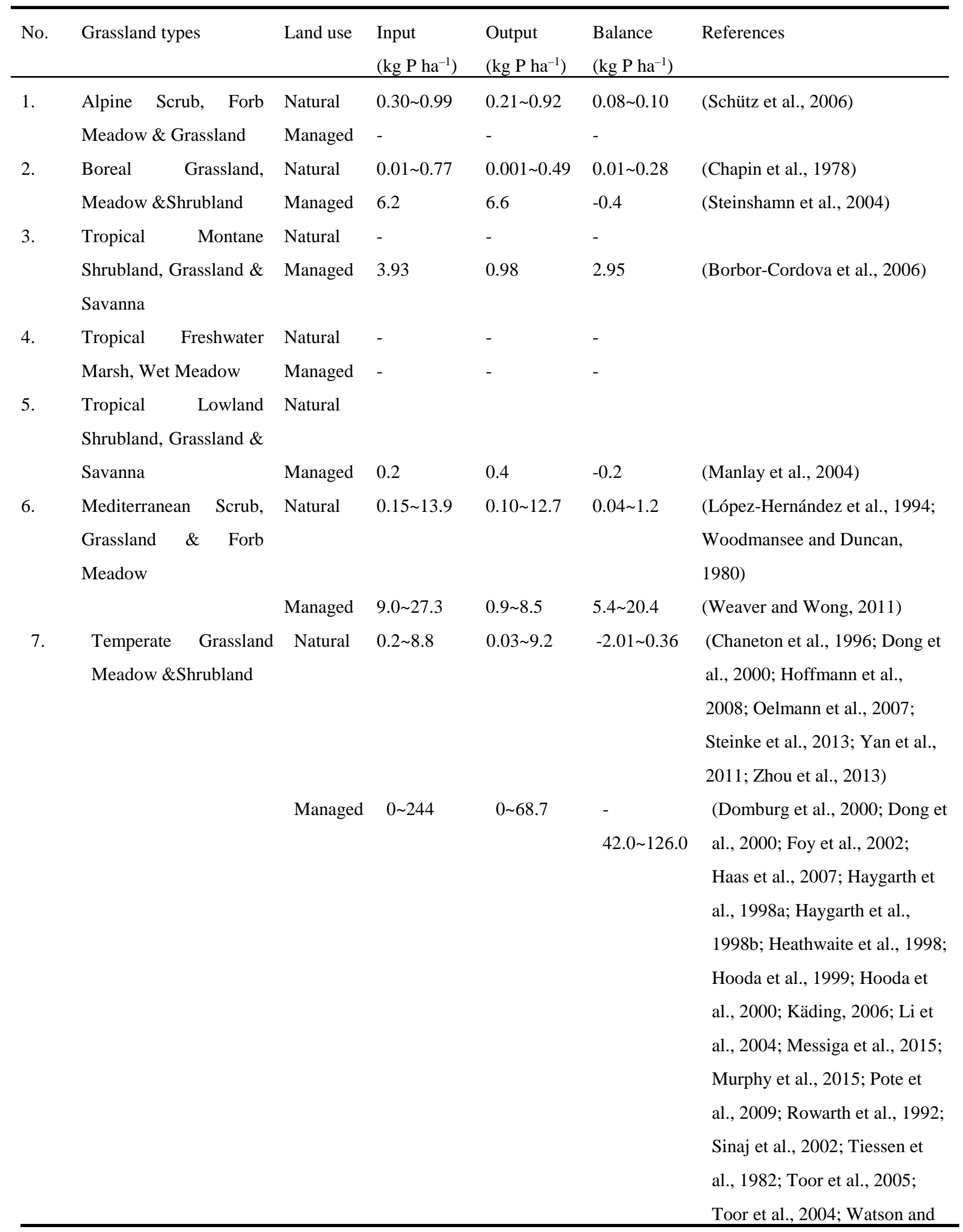


Matthews, 2008)

\begin{tabular}{|c|c|c|c|c|c|c|}
\hline \multirow[t]{2}{*}{8.} & Cool Semi-Desert Scrub & Natural & - & - & - & \\
\hline & \& Grassland & Managed & - & - & - & \\
\hline \multirow[t]{3}{*}{9.} & Warm Semi-Desert & Natural & $0.001 \sim 0.5$ & $0.01 \sim 0.31$ & $-0.05 \sim 0.2$ & (Newman, 1995; Schlesinger et \\
\hline & \multirow[t]{2}{*}{ Scrub \& Grassland } & & & & & al., 1999; Turnbull et al., 2011) \\
\hline & & Managed & $0.4 \sim 30.0$ & $1.4 \sim 13.0$ & $-1.0 \sim 25.8$ & $\begin{array}{l}\text { (Gourley et al., 2012; Obour et } \\
\text { al., 2011) }\end{array}$ \\
\hline
\end{tabular}




\section{Figure captions}

Fig. 1 Distribution of nine major grassland types in the world (based on Dixon et al., 2014).

Fig. 2 Conceptual illustration of P inputs and outputs in a grassland ecosystem. Figure adapted from Haygarth et al., 1998a.

Fig. 3. Global P input and output in natural grasslands.

Fig. 4. Global P input and output in managed grasslands.

Fig. 5. Flowchart of grassland management based on P balance 


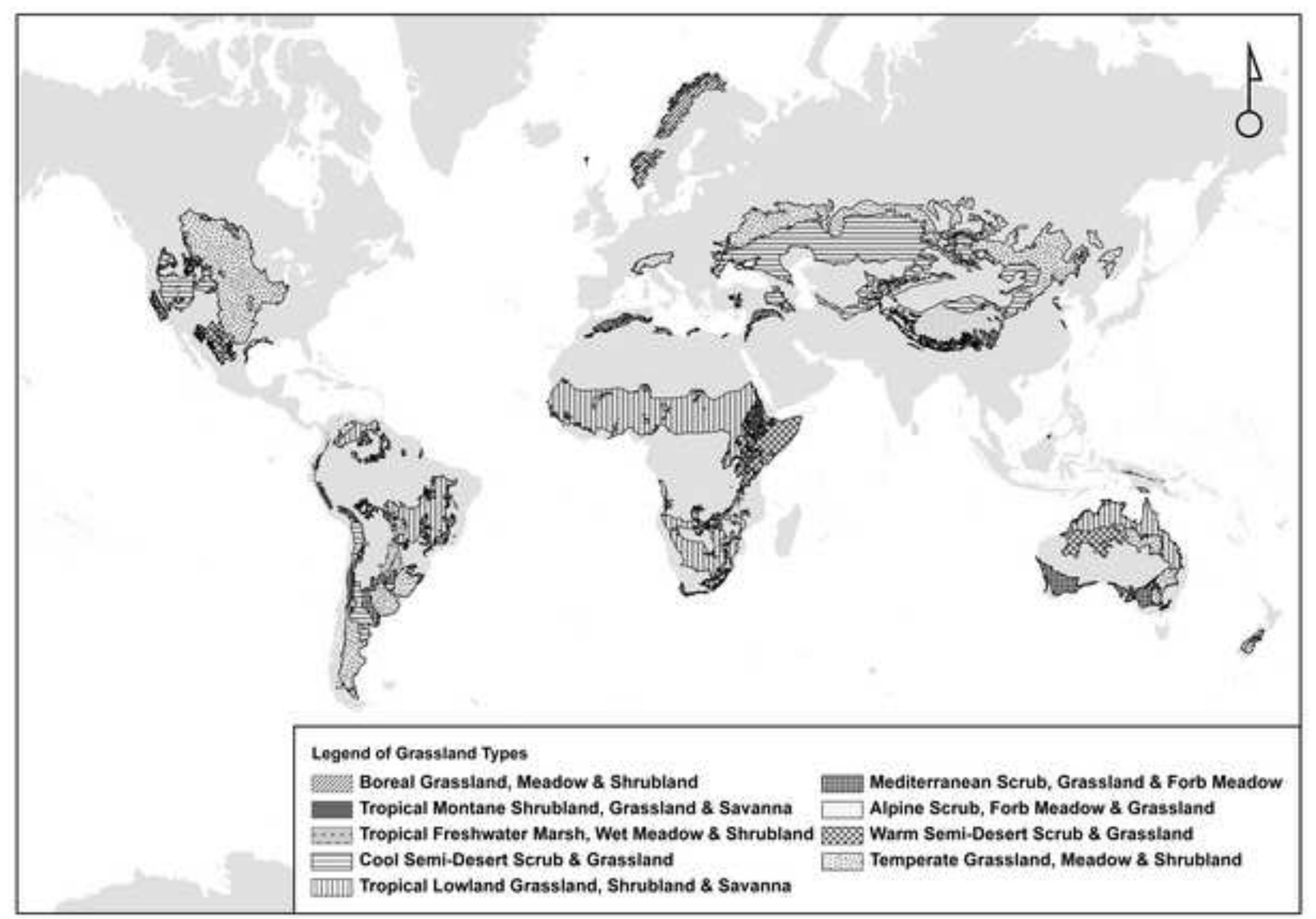




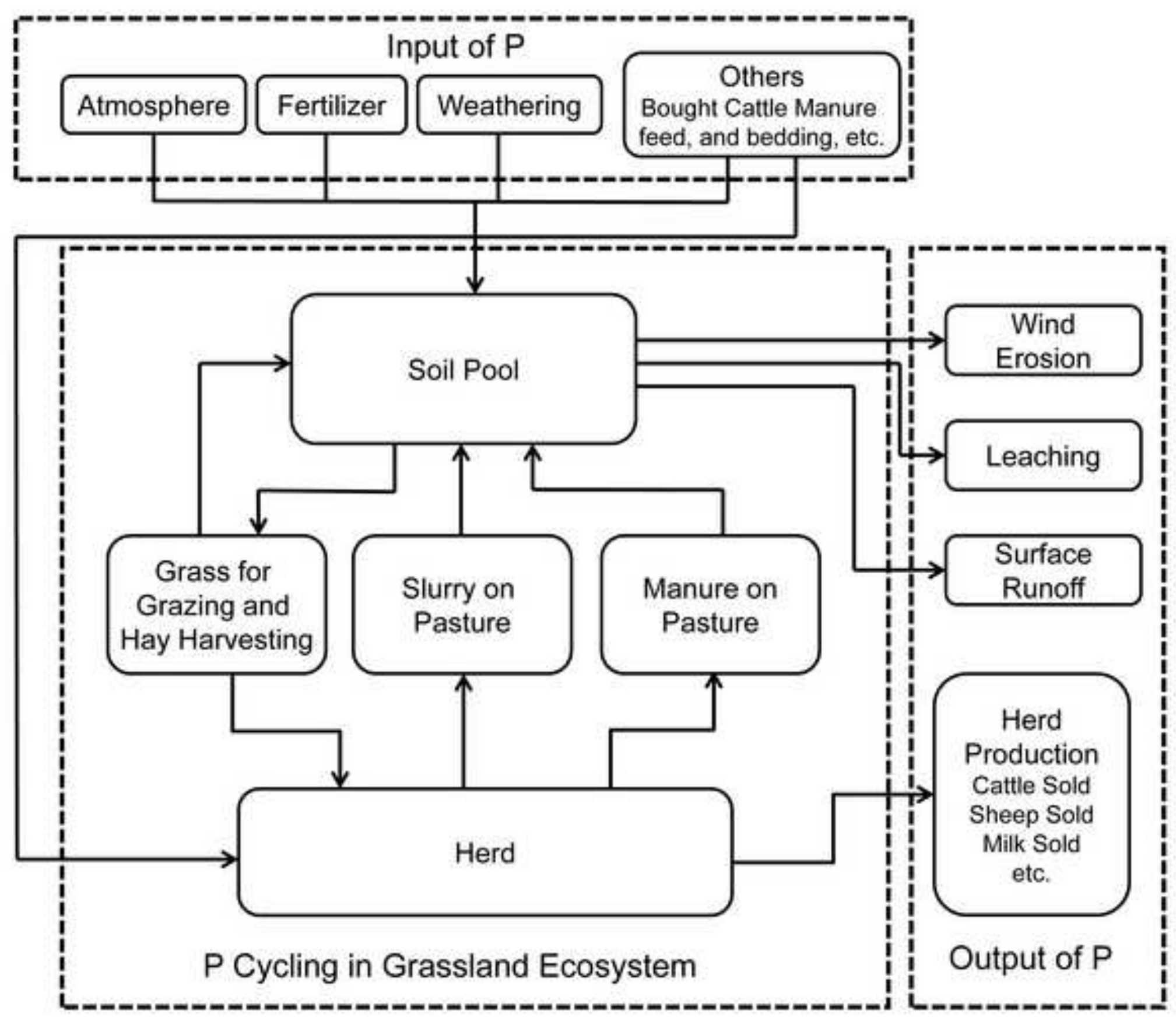




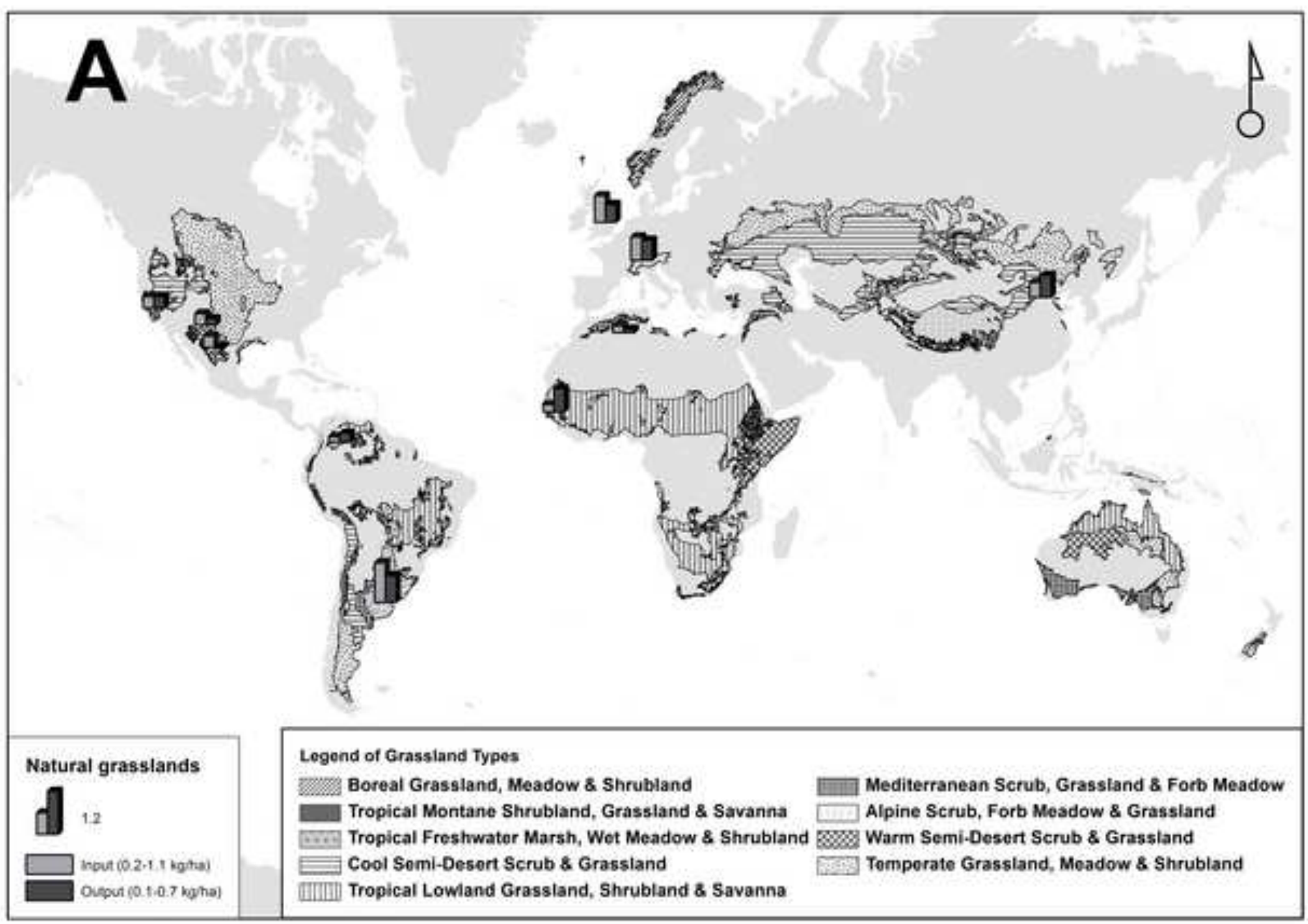




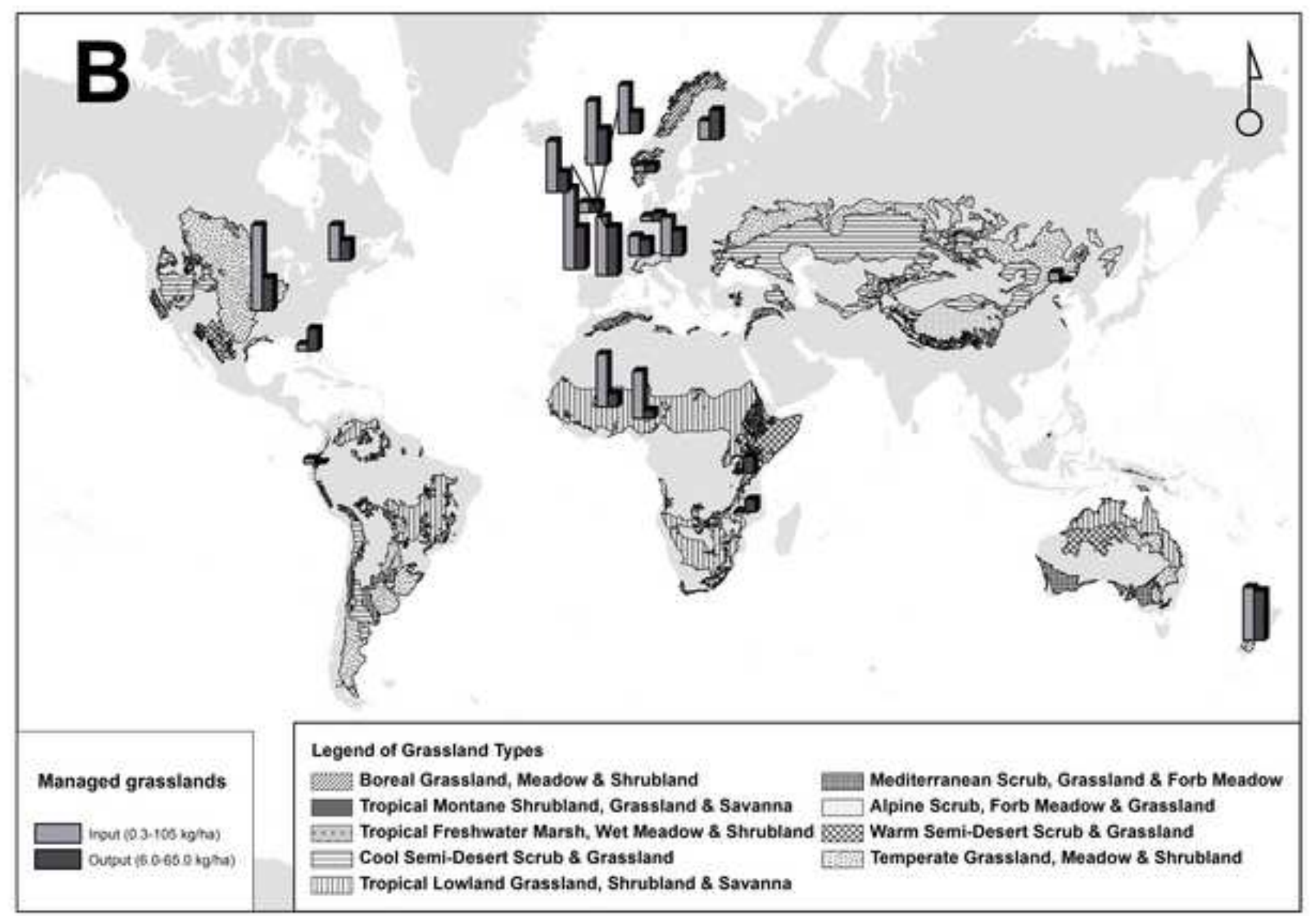




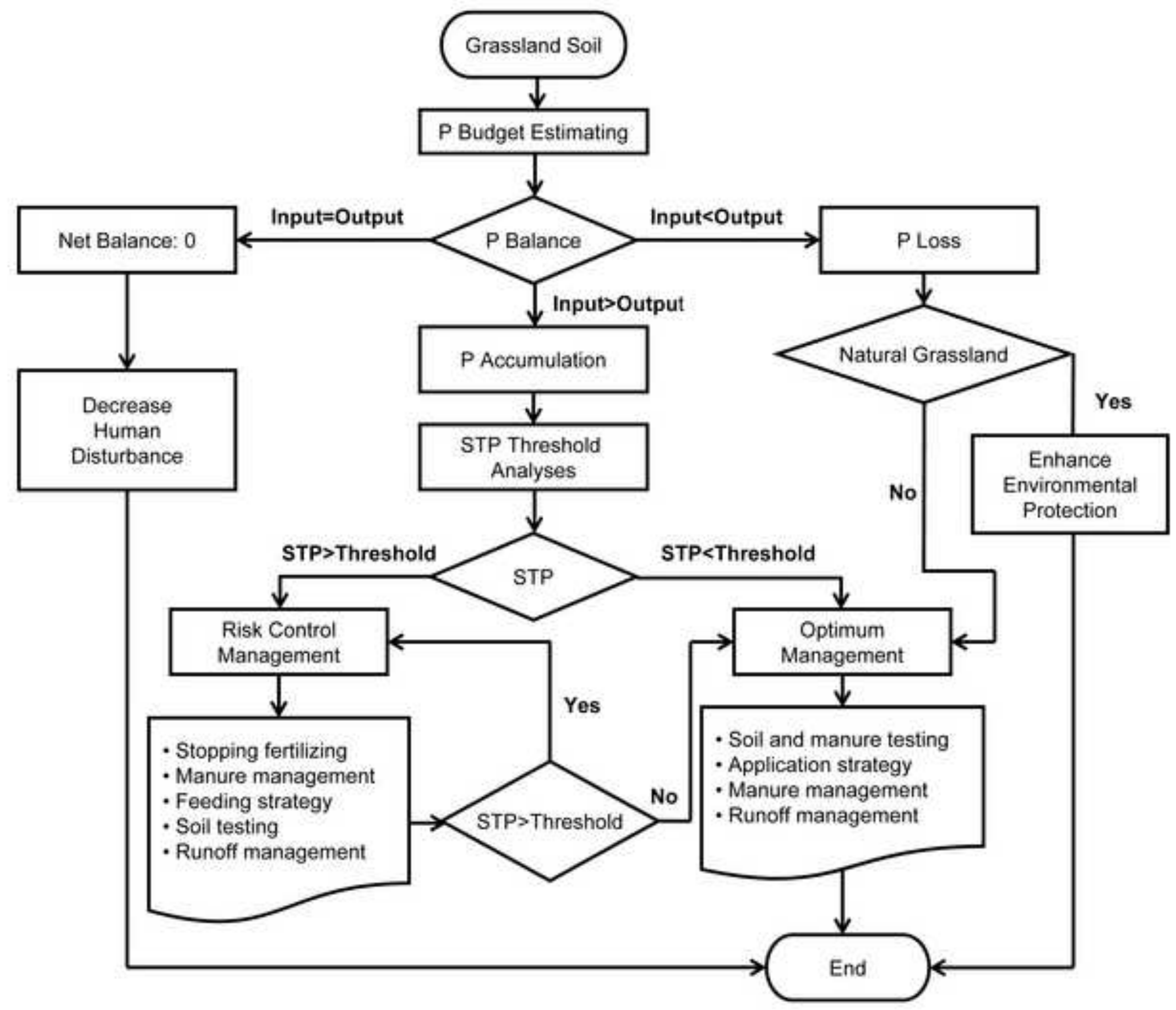

